\title{
The Effect of Ferrous Ions on the Formation of Toxin and Porphyrin by a Strain of Corynebacterium diphtheriae
}

\author{
By G. D. CLARKE \\ The Wright-Fleming Institute of Microbiology, St Mary's Hospital Medical School, \\ London, W. 2
}

SUMMARY: The effect of the iron concentration in the medium on the concentration of toxin and coproporphyrin in the culture filtrate of a strain of Corynebacterium diphtheriae has been found to differ quantitatively from that previously reported in the case of the P.W. 8 strain. Only 50-60\% of the iron present in the medium, at all concentrations tested, was recoverable from the organisms. Of the total iron present in the medium, only $9 \%$ was found to be present in the organisms as a haem complex capable of measurement as its pyridine haemochromogen. On the basis of their iron contents protohaemin and iron coproporphyrin III are less active than ferrous sulphate in their effect on toxin yield. These findings do not support the hypothesis that diphtheria toxin is the protein moiety of the cytochrome $b$ of the cell.

Campbell-Smith (1930) in England, and Coulter \& Stone (1930) in America reported the occurrence of a porphyrin-like pigment in diphtherial culture filtrates. It was noticed that when filtrates were stored in the light, the toxin and the pigment disappeared at the same rate, and attempts were made to correlate the formation of the two products during growth. The impression that the toxin and pigment were identical was dispelled by the demonstration (Wadsworth, Crowe \& Smith, 1935; Wheeler \& Crowe, 1936) that the pigment could be completely removed by charcoal treatment without decreasing the toxin titre. Pappenheimer \& Johnson (1936) found that there was an optimum concentration of iron in the medium for diphtheria toxin production. Any increase in the iron concentration of medium above this concentration led to a decrease in the toxin titre while causing no decrease in growth of the organism. Re-investigating these two phenomena quantitatively, Pappenheimer (1947) found that for every four atoms of iron added to the culture medium above that optimal for toxin production, four molecules of porphyrin and one molecule of toxin failed to appear in the culture filtrate. All the iron added to the medium over the range which inhibited toxin formation could be recovered from the bacterial cells. It was suggested that this evidence indicated that the toxin was the protein moiety of a respiratory enzyme of the organism. Pappenheimer \& Hendee (1947) investigated the formation of catalase, cytochromes $b$ and $c$ and cytochrome oxidase by two strains of Corynebacterium diphtheriae, and found that cytochrome $b$ was the main iron prophyrin-containing pigment of the organism; they suggested that cytochrome $b$ might be composed of iron, porphyrin and toxin.

Pappenheimer (1947) had found that the diphtheria porphyrin showed absorption curves almost identical with those of haematoporphyrin when 
examined in $\mathrm{N}-\mathrm{HCl}$ between 380 and $620 \mathrm{~m} \mu$. Gray \& Holt (1948) subsequently found that the main porphyrin component of diphtheria culture filtrates was in fact coproporphyrin III.

Pappenheimer investigated the changes in the succinoxidase activity of toxaemic guinea-pigs. Since cytochrome $b$ appears to be the rate-controlling compound in this enzyme system it might be expected that the effect of diphtheria toxin, if related to cytochrome $b$, would be to decrease the succinoxidase activity of the tissues. These observations were inconclusive, and further investigations into the action of the toxin were undertaken, using the Cecropia silk-worm. The injection of less than $1 \mu \mathrm{g}$. of diphtherial toxin into mature caterpillars, prepupae and developing adults caused a cessation of development and death in 1-5 weeks (Pappenheimer \& Williams, 1952). Dormant pupae, on the other hand, survived over 4 weeks after the injection of $70 \mu \mathrm{g}$. toxin, though $1 / 100$ of this dose prevented the pupae from initiating adult development. Maximum sensitivity to the toxin was found to be characteristic of those developmental stages which showed a cytochrome system; even within the diapausing pupae the toxin failed to affect heart muscle, from which the normal cytochrome sytem was absent, while it caused obvious degeneration of the intersegmental muscles which possessed an intact cytochrome system. This evidence strongly supported the thesis that the toxin acted on one or other components of the Cecropia cytochrome system. The arrest of adult development by toxin as opposed to the long latent period required before degenerative changes became evident was considered to indicate an interference with the synthesis of a component rather than with its function.

The quantitative investigations of Pappenheimer \& Hendee were carried out with the 'Toronto' P.W. 8 strain of Corynebacterium diphtheriae. The G/12/6 strain, used in this laboratory for routine toxin production, was known to differ in several important respects from the 'Toronto' strain. In particular, the G 12/6 strain produced higher toxin titres on a low nitrogen medium. It was therefore considered of interest to investigate whether the quantitative relationship of iron, toxin and porphyrin observed with the 'Toronto' strain also held for the G 12/6 strain. This paper describes the findings of this investigation, a preliminary note of which has already been published (Clarke \& Clarke, 1953).

\section{METHODS}

Organism. The strain used throughout was the G 12/6 strain of Corynebacterium diphtheriae used for routine toxin production in this laboratory.

Medium and conditions of growth. The medium used was a modification of that used by Holt (1948): acid hydrolysate of casein to $0.1 \%(w / v) ~ N$; cystine, $0.2 \mathrm{~g}$; nicotinic acid, $9 \mathrm{mg}$.; $\beta$-alanine, $2.3 \mathrm{mg}$.; pimelic acid, $0.15 \mathrm{mg}$.; $\mathrm{CuSO}_{4} .5 \mathrm{H}_{2} \mathrm{O}, 1 \mathrm{mg} ; \mathrm{ZnSO}_{4} .7 \mathrm{H}_{2} \mathrm{O}, 0 \cdot 8 \mathrm{mg}$.; $\mathrm{MnCl}_{2} .4 \mathrm{H}_{2} \mathrm{O}, 0 \cdot 3 \mathrm{mg}$.; maltose, 12.5 g.; lactic acid (A.R.), $3 \mathrm{ml}$.; $\mathrm{CaCl}_{2}$ (A.R. dried), $0.125 \mathrm{~g}$; distilled water to 11 .; $\mathrm{pH}$ adjusted to $6 \cdot 8$.

The casein hydrolysate, maltose and cystine were 'deferrated' as described by Holt (1948) and the maltose was autoclaved in the medium except in large- 
scale cultures, when it was autoclaved separately and added to medium auto-

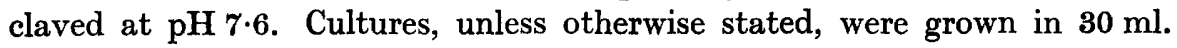
volumes of medium which had been autoclaved at $15 \mathrm{lb}$. $/ \mathrm{sq}$.in. $\left(115^{\circ}\right)$ for $15 \mathrm{~min}$. in $100 \mathrm{ml}$. Pyrex Erlenmeyer flasks. After inoculation by a loop of platinum wire from a $24 \mathrm{hr}$. pellicle, the cultures were incubated unshaken at $34^{\circ}$.

Toxin +toxoid titres. Toxin +toxoid was estimated by flocculation test (Ramon, 1922). When the value was $<25 \mathrm{Lf}$ units $/ \mathrm{ml}$. the filtrate was blended with a toxin of known titre before testing. In the sequel 'toxin' refers to toxin + toxoid determined in this way.

Amount of growth of organism. Bacterial growth was determined on salinewashed organisms by determination of total-N by the micro-Kjeldahl method (Markham, 1942).

Protein determination. The protein content of culture filtrates was determined by precipitation with $5 \%(\mathrm{w} / \mathrm{v})$ trichloroacetic acid and determination of total-N on the precipitate, after it had been washed with trichloroacetic acid.

Coproporphyrin determination. Coproporphyrin was extracted from culture filtrates by a modification of the method used by Pappenheimer (1947), and was determined spectrophotometrically. To $5 \mathrm{ml}$. of toxin filtrate in a beaker was added $5 \mathrm{ml} .10 \mathrm{~N}-\mathrm{HCl}$. The beaker was placed on a boiling water-bath in diffuse light for $10 \mathrm{~min}$. and then allowed to cool. To the beaker was then added $2.5 \mathrm{ml}$. glacial acetic acid, and the $\mathrm{pH}$ value adjusted to 3.6 with $50 \%$ $(\mathrm{w} / \mathrm{v}) \mathrm{NaOH}$. The solution was allowed to cool and then transferred quantitatively to a $50 \mathrm{ml}$. separating funnel. An equal volume of ether was added and the funnel shaken gently for $1 \mathrm{~min}$. The layers were allowed to separate completely before the water layer was run back into the beaker. The ether layer was washed twice with an equal volume of $0.1 \%(w / v)$ sodium acetate adjusted to $\mathrm{pH} \mathrm{3.6}$ with $\mathrm{N}-\mathrm{HCl}$, and the porphyrin then extracted by three volumes of $0 \cdot 1 \mathrm{~N}-\mathrm{HCl}$. The filtrate was returned to the funnel and the extraction process repeated. The $\mathrm{HCl}$ extracts were made up to $50 \mathrm{ml}$. and compared with a standard solution of coproporphyrin III in $0 \cdot 1 \mathrm{~N}-\mathrm{HCl}$ at the Soret peak (402 $\mathrm{m} \mu$.).

Iron determination. The iron concentration in the organisms was determined by the o-phenanthroline method (Saywell \& Cunningham, 1937; Fortune \& Mellon, 1938). The saline-washed organisms were dried at $160^{\circ}$ in Pyrex test tubes and heated gently with $1 \mathrm{ml}$. of combustion mixture (redistilled $\mathrm{HNO}_{3}, 80$ vol.: $\mathrm{HClO}_{4}$ (A.R.), 5 vol.: $\mathrm{H}_{2} \mathrm{SO}_{4}$ (A.R.), 3 vol.) until all solid matter had disintegrated. The tubes were then kept in a water bath at $c .80^{\circ}$ for $3 \mathrm{hr}$. and finally heated slowly until colourless. After cooling, $1 \mathrm{ml}$. of distilled water was added to each tube, followed by $0.4 \mathrm{ml}$. of $10 \%(\mathrm{w} / \mathrm{v})$ hydroxylamine hydrochloride (A.R.) and $0.25 \mathrm{ml}$. of a $1 \%(\mathrm{w} / \mathrm{v})$ solution of $o$-phenanthroline (A.R.). The reaction was adjusted to $\mathrm{pH} 6 \cdot 0 \pm 1 \cdot 0$ with $\mathrm{NH}_{4} \mathrm{OH}$ (A.R.) by using a micropipette and an external indicator paper. The tubes were kept at $20-25^{\circ}$ for $2 \mathrm{hr}$., and then made up to $20 \mathrm{ml}$. The iron content was determined by comparison with a standard, using a blue-green filter in a Hilger spectrophotometer. 
Metalloporphyrin. The iron complex of coproporphyrin III was obtained by saponification of its tetramethyl ester prepared by the method used by Fischer \& Orth (1937) for the I tetramethyl ester.

Haem determination. The haem content of organisms was determined by the pyridine haemochromogen method of Pappenheimer \& Hendee (1949), or by extraction by the method of Rawlinson \& Hale (1949) as indicated.

\section{RESULTS}

\section{Toxin and porphyrin concentration}

In order to relate toxin and porphyrin concentrations to the amount of iron added to the medium it was necessary to determine after what period of incubation these concentrations were maximum, at which concentrations only could legitimate comparison be made. Fig. 1 shows the results of growth at optimum iron concentration $(0 \cdot 2 \mu \mathrm{g} . / \mathrm{ml}$.) and optimum iron concentration $+0 \cdot 2 \mu \mathrm{g} . \mathrm{Fe} / \mathrm{ml}$. After 7 days of incubation the bacterial-N was beginning to decline, but the toxin and porphyrin concentrations were approximately maximum. The graph of $\mathrm{pH}$ value with time shows that the $\mathrm{pH}$ values varied between $6 \cdot 6$ and $7 \cdot 9$, between which limits toxin and coproporphyrin were found to be stable under the conditions of growth. In some experiments the $\mathrm{pH}$ value fell as low as $\mathbf{6 \cdot 2}$ for a period of $24 \mathrm{hr}$., but at this $\mathrm{pH}$ value there was no decrease in toxin titre during $48 \mathrm{hr}$.

\section{Effect of iron on toxin and porphyrin formation}

'The term 'formation' is used to mean the appearance of toxin and porphyrin in the culture filtrate during the growth of the diphtheria bacillus. Whether or not this is a true index of the formation of these substances by the cells depends on their existence in the cells, before their appearance in the filtrate, in a concentration in excess of that found in the filtrate (Raynaud et al. 1954). It is known that both toxin and coproporphyrin, once released, remain stable in the filtrate for a considerable time, and the concentrations determined are thus a true indication of the amounts released from cells up to the time of harvesting.

The effect of the addition of ferrous sulphate, in concentrations up to $0.86 \mu \mathrm{g}$. iron $/ \mathrm{ml}$. culture medium, on the toxin and coproporphyrin release, is shown in Table 1. The cultures were harvested after 7 days of incubation at $34^{\circ}$ when the toxin and coproporphyrin yields were at a maximum. It can be seen that the increase in iron concentration had little effect on the growth of the culture as indicated by the bacterial-N determinations on washed organisms. The relationship between iron added and the toxin and porphyrin failing to appear in the culture filtrate is shown in Fig. 2. These figures, expressed in molar concentrations with the molecular weight of diphtheria toxin being taken as 72,000 (Pappenheimer, 1942), indicate that approximately 1 molecule of toxin and 2 molecules of porphyrin failed to appear in the culture filtrate for every 2 atoms of iron added to the medium in excess of that required for maximum toxin formation. Iron determinations on washed organisms, 


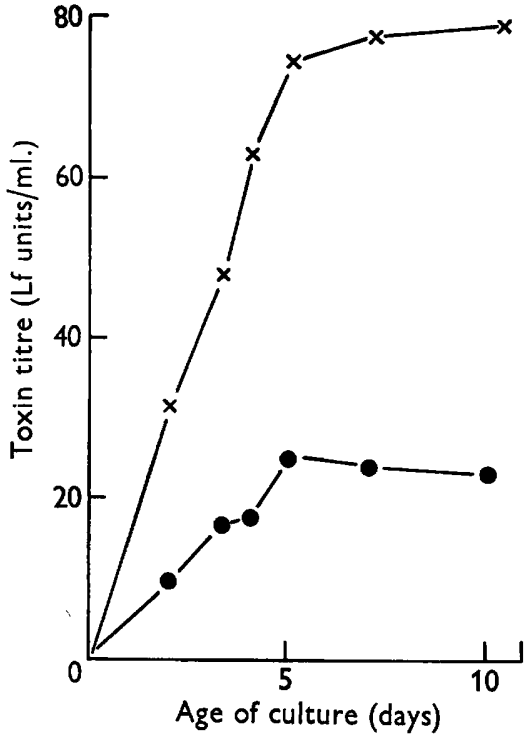

(a)

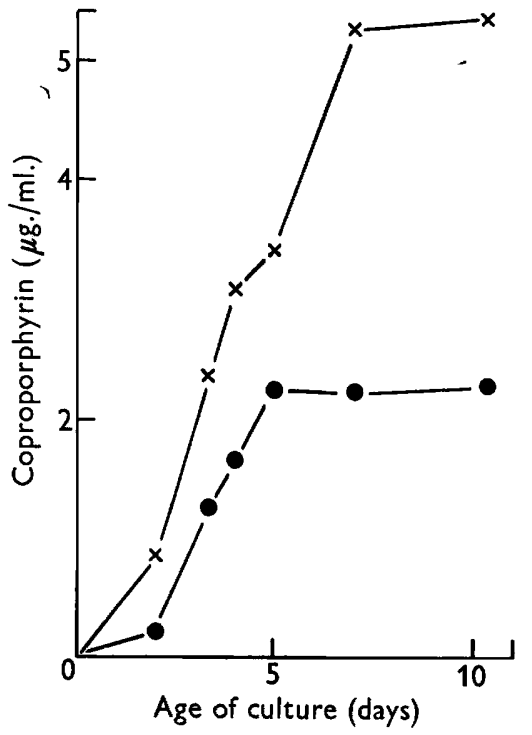

(c)

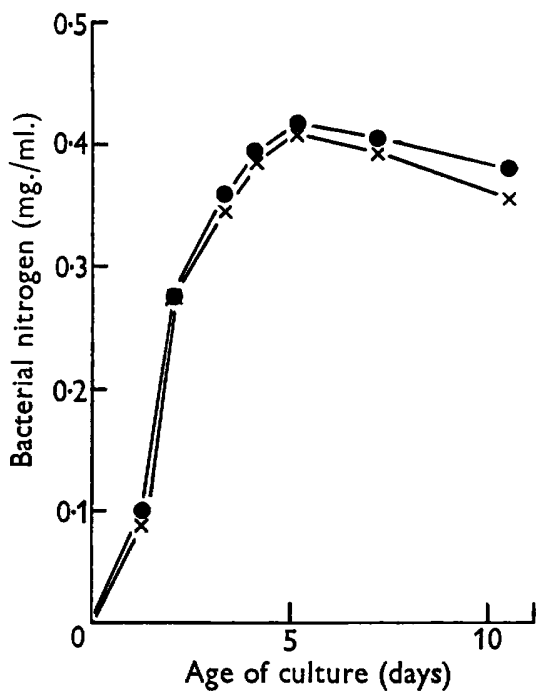

(b)

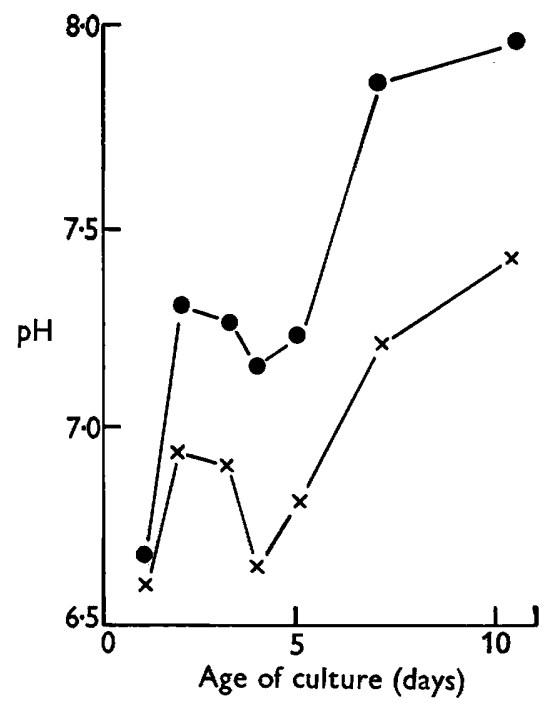

(d)

Fig. 1. Cultures of $C$. diphtheriae grown at $34^{\circ}$ for 10 days containing: $\times-\times, 0 \cdot 22 \mu \mathrm{g}$. of iron per ml. ; $-0.42 \mu \mathrm{g}$. of iron per $\mathrm{ml}$. (a) Toxin titre of culture filtrate; $(b)$ bacterial nitrogen; $(c)$ coproporphyrin concentration in culture filtrate ; $(d) \mathrm{pH}$. 
Table 1. The effect of increasing iron concentrations on the toxin titre and coproporphyrin concentration in filtrates of cultures of Corynebacterium diphtheriae strain $\boldsymbol{G}$ 12/6

$30 \mathrm{ml}$. cultures in $100 \mathrm{ml}$. conical flasks (Pyrex) were incubated for 7 days at $34^{\circ}$. Organisms were centrifuged down and washed twice with $0.85 \%(\mathrm{w} / \mathrm{v}) \mathrm{NaCl}$ solution. All values are averages of duplicate cultures.

$\begin{array}{cccccc}\begin{array}{c}\text { Iron conen. } \\ \text { in medium } \\ (\mu \mathrm{g} . / \mathrm{ml} .)\end{array} & \begin{array}{c}\text { Toxin } \\ \text { titre } \\ (\mathrm{Lf} / \mathrm{ml})\end{array} & \begin{array}{c}\text { Bacterial-N } \\ (\mu \mathrm{g} . / \mathrm{ml} .)\end{array} & \begin{array}{c}\text { Copropor- } \\ \text { phyrin } \\ (\mu \mathrm{g} \cdot / \mathrm{ml} .)\end{array} & \begin{array}{c}\text { Bacterial-Fe } \\ (\mu \mathrm{g} . / \mathrm{ml})\end{array} & \text { pH value } \\ \mathbf{0 \cdot 2 0} & 92 & 350 & 5 \cdot 3 & 0 \cdot 11 & 6 \cdot 71 \\ 0 \cdot 24 & 85 & 355 & 4 \cdot 8 & 0 \cdot 13 & 6 \cdot 74 \\ 0 \cdot 28 & 75 & 365 & 4 \cdot 3 & 0 \cdot 14 & 6 \cdot 76 \\ 0 \cdot 32 & 65 & 370 & 4 \cdot 0 & 0 \cdot 16 & 6 \cdot 68 \\ 0 \cdot 40 & 45 & 340 & 3 \cdot 5 & 0 \cdot 23 & 6 \cdot 71 \\ 0 \cdot 56 & 10 & 350 & 1 \cdot 15 & 0 \cdot 31 & 6 \cdot 66 \\ 0 \cdot 86 & 3 & 365 & 0 \cdot 40 & 0 \cdot 44 & 6 \cdot 71\end{array}$

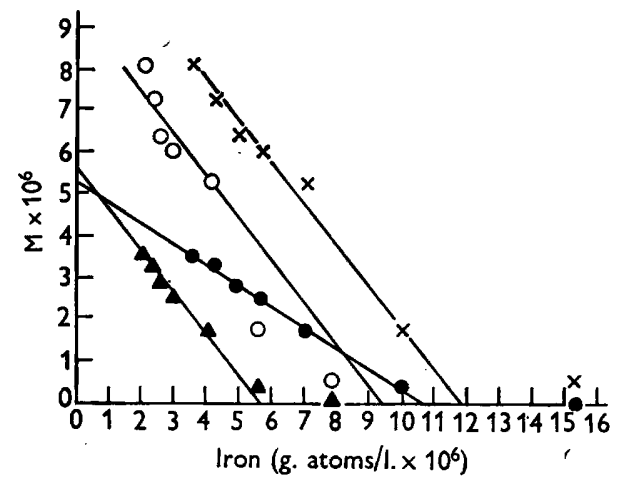

Fig. 2. Toxin and coproporphyrin concentrations related to iron in medium and cells

Toxin, and $x-x$, coproporphyrin, related to iron concentration in medium. $\boldsymbol{A}-\boldsymbol{\Delta}$, Toxin and $\mathrm{O}-\mathrm{O}$, coproporphyrin related to iron in washed cells. Cultures of $\boldsymbol{C}$. diphtheriae grown at $34^{\circ}$ for 7 days. The lines represent ratios of $1: 1$ and $2: 1$ respectively.

however, indicated that little over half the iron present in the medium was recoverable from the organisms, and the relationship should logically be based on these figures if, as is postulated, these substances exist in combination within the organisms. On this basis (Fig. 2) there is reasonable agreement with the relationship 1 atom of iron:2 molecules coproporphyrin: 1 molecule toxin, except at higher iron concentrations, where the effect of iron is less marked.

\section{The haem content of organisms}

It is not satisfactory, in calculating the quantitative relationship between iron, toxin and porphyrin, to use the figures for the iron contained in the organisms, unless it can be shown that a major proportion of this iron exists or has existed in the hypothetical complex with toxin and porphyrin, namely, cytochrome $b$. It was shown by Rawlinson \& Hale (1949) that cytochrome $b$ is the main cytochrome component of the diphtheria bacillus. They found that 1.0-1.1 mg. protohaemin/l. culture could be extracted from the organisms. 
This figure would contain the protohaemin from cytochrome $b$, but also, in all probability, some from catalase and peroxidase (if present), since it has been shown that haemin can be obtained from these enzymes, in other systems, by the $\mathrm{HCl}$-acetone extraction procedure used by Rawlinson \& Hale (Stern, 1936; Theorell, 1940).

Five l. medium containing an iron concentration just sufficient to depress the toxin concentration below that measurable by flocculation ( $3 \mathrm{Lf} \mathrm{units} / \mathrm{ml}$.) were inoculated with the G 12/6 strain and incubated for 7 days. The organisms were harvested by centrifugation and washed twice with $0 \cdot 85 \%(w / v) ~ N a C l$ solution. The protohaemin was then extracted by the method used by Rawlinson \& Hale (1949), which consisted of defatting with ethanol and acetone, exhaustive extraction of the haemin with $\mathrm{HCl}$ acetone, washing the crude extract with ether, $\mathrm{HCl}$ and $\mathrm{NaCl}$ solutions, and removal of the haemin into $0 \cdot 1 \mathrm{~N}-\mathrm{KOH}$. The KOH solution of crude haemin was neutralized with $\mathrm{HCl}$ and $\mathrm{CO}_{2}$ bubbled through it; after being kept at $2^{\circ}$ for $18 \mathrm{hr}$. the haemin was centrifuged down, dissolved in a pyridine + chloroform mixture, and determined spectrophotometrically (Holden, 1941). Of the total iron present in original medium ( $0.65 \mu \mathrm{g}$. $/ \mathrm{ml}$.), haemin equivalent to $0.028 \mu \mathrm{g}$. iron $/ \mathrm{ml}$. was found in the extract in the present experiment. Thus $60 \%$ of the available iron was recoverable from the organisms, and of this only $7 \%$ was recovered as haemin. The extraction procedure was carried out quantitatively and added haemin was found to be accurately determined by this method; moreover, none was detected in the residue as pyridine haemochromogen. However, it was thought possible that a significant amount of haemin might have been adsorbed on to the bacterial residue. The proportion of haem and non-haem iron present in organisms harvested after 1-7 days of growth was therefore investigated, determining haem in cell debris after sonic disintegration (Pappenheimer \& Hendee, 1949).

The organism was grown on a medium containing $0.75 \mu \mathrm{g}$. iron $/ \mathrm{ml}$., $200 \mathrm{ml}$. cultures being incubated in $1 \mathrm{l}$. bottles. Duplicate determinations of bacterial$\mathrm{N}$ and iron were made on unwashed organisms from two bottles taken at intervals throughout the incubation period, and haem-iron was determined on a suspension of organisms after $30 \mathrm{~min}$. distintegration in a Mullard Ultrasonic Generator E. 7590A at $20 \mathrm{kcyc}$. $/ \mathrm{sec}$. The results (Table 2) confirm previous results in that only $66 \%$ of the iron was found in the organisms. The haem-iron content of the organisms, increasing somewhat during incubation, was never more than $14 \%$ of the iron content or $9 \%$ of the total iron concentration in medium.

Since only a small proportion of the iron present in the diphtheria bacilli could be demonstrated to be present as haem, the comparative effects of ferrous iron and haemin iron in preventing the release of toxin were investigated, and as coproporphyrin III was the main porphyrin released by the organism under conditions of iron deficiency, the effect of iron coproporphyrin III complex was also tested. Table 3 shows the effect on the toxin titre of culture filtrates at 7 days compared with a control culture which contained concentration of iron optimum for toxin production. Haemin and iron 
Table 2. The iron and haem content of organisms in cultures of Corynebacterium diphtheriae strain $G$ 12/6

Organisms were harvested at intervals from $2 \times 200 \mathrm{ml}$. cultures containing 0.75 $\mu \mathrm{g}$. iron $/ \mathrm{ml}$. Incubation at $34^{\circ}$. Duplicate determinations of bacterial-Fe and $-\mathrm{N}$ made on unwashed organisms.

$\begin{array}{cccccc}\begin{array}{c}\text { Incubation } \\ \text { time } \\ (\mathrm{hr} .)\end{array} & \begin{array}{c}\text { Bacterial-N } \\ (\mu \mathrm{g} . / \mathrm{ml} .)\end{array} & \begin{array}{c}\text { Bacterial-Fe } \\ (\mu \mathrm{g} . / \mathrm{ml} .)\end{array} & \begin{array}{c}\text { Bacterial- } \\ \text { haem } \\ (\mu \mathrm{g} . / \mathrm{ml})\end{array} & \begin{array}{c}\text { Bact.-Fe } \\ \text { Total-Fe }\end{array} & \begin{array}{c}\text { Haem-Fe } \\ \text { Bact.-Fe }\end{array} \\ 43 & 0 \cdot 205 & 0 \cdot 21 & 0 \cdot 19 & 0 \cdot 28 & 0 \cdot 09 \\ 66 & 0 \cdot 320 & 0 \cdot 31 & 0 \cdot 27 & 0 \cdot 41 & 0 \cdot 09 \\ 92 & 0.455 & 0 \cdot 37 & 0.48 & 0 \cdot 49 & 0 \cdot 13 \\ 113 & 0.525 & 0 \cdot 41 & 0.56 & 0 \cdot 55 & 0 \cdot 14 \\ 161 & 0.515 & 0.50 & 0 \cdot 65 & 0 \cdot 66 & 0 \cdot 13 \\ & 0.475 & 0.50 & 0.69 & 0 \cdot 66 & 0 \cdot 14\end{array}$

Table 3. The relative effects of iron, iron coproporphyrin $I I I$, and protohaemin on the toxin titre of cultures of Corynebacterium diphtheriae strain $G$ 12/6

$30 \mathrm{ml}$. cultures in $100 \mathrm{ml}$. conical flasks (Pyrex) were incubated for 7 days at $34^{\circ}$. The basal medium contained $\mathbf{0 . 2 1} \mu \mathrm{g}$. iron $/ \mathrm{ml}$. Metalloporphyrin solutions were sterilized separately.

$\quad$ Addition
$\mathrm{Nil}_{4}$
$\mathrm{FeSO}_{4}$
$\mathrm{FeSO}_{4}$
$\mathrm{Haemin}$
Haemin
Haemin
Iron coproporphyrin

$\begin{array}{cc}\begin{array}{c}\text { Fe concentration } \\ \text { added }(\mu \mathrm{g} . / \mathrm{ml} .)\end{array} & \begin{array}{c}\text { Toxin titre } \\ \text { (Lf units } / \mathrm{ml} .)\end{array} \\ \text { Nil } & 73 \\ 0 \cdot 1 & 49 \\ 0 \cdot 2 & 17 \\ 0 \cdot 3 & 7 \\ 0 \cdot 1 & 73 \\ 0 \cdot 2 & 63 \\ 0 \cdot 3 & 49 \\ 0 \cdot 15 & 64\end{array}$

coproporphyrin III complex both caused a decrease in toxin titre, but this decrease was less than that caused by adding ferrous iron.

\section{DISCUSSION}

The hypothesis which explains the role of diphtheria toxin in the diphtheria bacillus as that of the protein moiety of cytochrome $b$, and its toxic effects in mammals as due to interference with the synthesis of the specific mammalian cytochrome $b$ is attractive, and has been supported by a quantity of largely circumstantial evidence. Pappenheimer showed that the 'Toronto' P.W.8 strain of Corynebacterium diphtheriae gave a close quantitative relationship between the amount of iron added to the culture medium in excess of that required for maximum toxin formation and the amounts of toxin and porphyrin which failed, under these conditions, to appear in the culture filtrate. The ratio of four atoms of iron and four molecules of porphyrin to one molecule of protein corresponds with that found in cytochrome $b$. The relationship, however, is based on the molar extinction coefficient of the porphyrin as approximating to that of haematoporphyrin, namely, $3.46 \times 10^{5} \mathrm{in} \mathrm{N}-\mathrm{HCl}$, on the fact that all the iron is recoverable from the organisms, and that this iron is present in the organisms largely as cytochrome $b$. 
It was shown by Gray \& Holt that the porphyrin was in fact predominantly coproporphyrin III whose molar extinction coefficient in $\mathrm{N}-\mathrm{HCl}$ is $\mathbf{5 \cdot 3} \times \mathbf{1 0} 0^{\mathbf{5}}$. The present communication has described several respects in which the $\mathbf{G} 12 / 6$ strain differs in behaviour from the 'Toronto' P.W.8 strain. At any concentration up to that required to decrease the toxin titre to less than $3 \mathrm{Lf}$ units/ $\mathrm{ml}$. only $60 \%$ of the iron present in the medium is recoverable from the organisms. The quantitative relationship between the iron, coproporphyrin and toxin is not the same as that with the 'Toronto' P.W. 8 strain, nor does a constant relationship hold for all iron concentrations, since there is a decrease in the effect of iron as its concentration increases; when only bacterial iron is considered, the departure from these proportions is even greater.

If haemin, as determined by the haemochromogen method of Pappenheimer, is a reliable indication of cytochrome $b$ haem, then only $9 \%$ of the iron present in the medium initially is converted to cytochrome $b$. This means that there is no quantitative evidence for assuming that iron, porphyrin and toxin comprise diphtherial cytochrome $b$, in the G 12/6 strain. Moreover, though cytochrome $b$ is undoubtedly the main iron porphyrin enzyme of the diphtheria bacillus, it is only responsible for $16 \%$ of its iron content.

In assessing the present results it is necessary to bear in mind that the cultures on which these measurements were made represent a dynamic system. Toxin and coproporphyrin, once released into the culture medium, are stable under the conditions of growth for the period (7 days) of the observations, but it remains a possibility that diphtherial cytochrome $b$ has a short life, and that more cytochrome $b$ has been synthesized in the cells in the 7 days' period of growth than is determined in the final culture. There is little evidence for such a short life for respiratory enzymes however, and during this period there is insufficient lysis materially to invalidate the interpretation of the analytical results. In this connexion it is well to record that only $10 \%$ of the porphyrin nuclei present as coproporphyrin at low iron concentrations were demonstrable as haem in conditions of iron excess; a similar situation was described by Lascelles (1956). Suspensions of Rhodopseudomonos spheroides converted glycine and $\alpha$-oxoglutarate into porphyrins in medium of low iron concentration. When the iron content of the medium was increased, however, bacteriochlorophyll and haem were formed, which only accounted for 10 and $1 \%$, respectively, of the porphyrins which fail to appear in the free state. It may be said that, with the conditions of static culture used in the present investigation, there was found no quantitative evidence to support any relationship between toxin and cytochrome $b$ in the $\mathbf{G} 12 / 6$ strain of Corynebacterium diphtheriae.

\section{REFERENCES}

Campbell-Smith, F. (1930). The nature of diphtheria toxin-antitoxin floccules. Lancet, i, 529.

Clarke, W. A. \& Clarke, G. D. (1953). The mechanism of the effect of iron and cobalt on the production of toxin by Corynebacterium diphtheriae. Biochem. J. 55 , xvi. 
Coulter, C. B. \& Stone, F. M. (1930). The occurrence of porphyrins in cultures of Corynebacterium diphtheriae. J. gen. Physiol. 14, 583.

Fischer, H. \& Orth, H. (1937). Die Chemie des Pyrrols. Pyrrolfarbstoffe, II. Erste Hälfte. Leipzig: Academische Verlagsgesellschaft.

Fortune, W. B. \& Mellon, M. G. (1938). Determination of iron with o-phenanthroline. Industr. Engng Chem. (Anal.) 10, 60.

Gray, C. H. \& Holt, L. B. (1948). The isolation of coproporphyrin III from Corynebacterium diphtheriae culture filtrates. Biochem. J. 43, 191.

HoldEN, F. H. (1941). The ultraviolet absorption spectra of some metalloporphyrins and of their compounds with globin. Aust. J. exp. Med. biol. Sci. 19, 1.

HoLt, L. B. (1948). The preparation of purified and concentrated diphtheria toxoid from a semi-synthetic medium. Brit. J. exp. Path. 29, 335.

LAScelles, J. (1956). The synthesis of porphyrins and bacterial chlorophyl by cell suspensions of Rhodopseudomonas spheroides. Biochem. J. 62, 78.

MarkhaM, R. (1942). A steam-distillation apparatus suitable for micro-Kjeldahl analysis. Biochem. J. 36, 790.

Pappenheimer, A. M., Jun. (1942). Studies on diphtheria toxin and its reaction with antitoxin. J. Bact. 43, 273.

Pappenheimer, A. M., Jun. (1947). Diphtheria toxin. III. A reinvestigation of the effect of iron on toxin and porphyrin production. J. biol. Chem. 167, 251.

Pappenheimer, A. M., Jun. \& Hendee, E. D. (1947). Diphtheria toxin. IV. The iron enzymes of Corynebacterium diphtheriae and their possible relationship to diphtheria toxin. J. biol. Chem. 171, 701.

Pappenheimer, A. M., Jr. \& Hendee, E. D. (1949). Diphtheria toxin. V. A comparison between the diphtherial succinoxidase system and that of beef heart muscle. J. biol. Chem. 180, 597.

Pappenheimer, A. M., Jr. \& Johnson, S. J. (1936). Studies in diphtheria toxin production. I. The effect of iron and copper. Brit. J. exp. Path. 17, 335.

Pappenheimer, A. M., Jr. \& Williams, C. M. (1952). The effect of diphtheria toxin on the Cecropia silkworm. J. gen. Physiol. 35, 727.

Ramon, G. (1922). A propos du titrage in vitro du serum antidiphthérique par la floculation. C.R. Soc. Biol., Paris, 86, 813.

Rawlinson, W. A. \& Hale, J. H. (1949). Prosthetic groups of the cytochromes present in Corynebacterium diphtheriae with especial reference to cytochrome $a$. Biochem. J. 45, 247.

Raynaud, M., Turpin, A., Mongola, B., Bizzini, B. \& Pery, R. (1954). Croissance et Toxinogenèse. Ann. Inst. Pasteur, 87, 599.

Sayweld, L. G. \& Cunningham, B. B. (1937). Determination of Iron. Colorimetric $o$-phenanthroline method. Industr. Engng Chem. (Anal.) 9, 67.

Stern, K. G. (1936). The constitution of the prosthetic group of catalase. J. biol. Chem. 112, 661 .

Theonell, H. (1940). Reversible Spaltung einer Peroxydase. Ark. Kemi Min. Geol. 148, No. 20.

Wadsworth, A., Crowe, M. O'L. \& Smith, L. A. (1935). The spectroscopic investigation of bacterial toxins: the absorption spectra of the products of Corynebacterium diphtheriae. Brit. J. exp. Path. 16, 201.

Whenler, M. W. \& Crowe, M. O'L. (1936). A note on conditions affecting the production of toxin and porphyrins by the diphtheria bacillus. J. Bact. 31, 519.

(Received 30 December 1957) 